\title{
Influence of types of constitution on meat productivity bullets of Simmental breed
}

\author{
Anatoly Shevkhuzhev ${ }^{1}$, Vladimir Pogodaev ${ }^{1, *}$, and Dagir Smakuev ${ }^{2}$ \\ ${ }^{1}$ North Caucasian Federal Scientific Agrarian Center, 49, st. Nikonova, 546241, Mikhailovsk, Russia \\ ${ }^{2}$ North Caucasian State Academy, 36, st. Stavropolskaya, 369000, Cherkessk, Russia
}

\begin{abstract}
The aim of the research was to establish quantitative and qualitative indicators of meat productivity of Simmental bull calves of various constitutional types when raised using the technology of beef cattle breeding. The maximum growth rate and the highest yield of meat products were obtained from Simmental bulls of the meat and dairy type when they were raised and fed according to the technology of beef cattle breeding. Receiving from the mothers for 205 days of the sucking period more fatty milk, they gave $1250 \mathrm{~g}$ of gain per day and reached $289.7 \mathrm{~kg}$ of live weight by the cut. Having retained a high growth rate in the future, they at the final fattening gave $1321 \mathrm{~g}$ of gain per day and at 20 months the live weight was $659.3 \mathrm{~kg}$. The superiority of Simmentals over analogues was natural by $3.4-13.3 \%$ by weight of the steamed carcass, by $0.4-1.8 \%$ in slaughter yield, by $1.4-11.1 \mathrm{~kg}$ in terms of the amount of pulp in the carcass and pulp per bones by $0.1-0.3 \mathrm{~kg}$, protein in meat by $0.12 ; 1.19$; $2.59 \mathrm{~kg}$ and the amount of energy in the pulp by $0.14 ; 0.44 ; 1.75 \mathrm{MJ}$. Simmental bulls of the meat and dairy type also have a high ability to transform protein and feed energy into protein and energy from the pulp of the carcass.
\end{abstract}

\section{Introduction}

The main tasks now facing beef cattle are: the introduction of low-cost technologies, the solution of many issues related to the reproduction of the herd, the creation of cultural pastures, the intensive use of highly productive bulls-producers. The Simmental breed is characterized by a high acclimatization ability, a successful combination of milk productivity with a high live weight and good meat qualities [1-6].

The Simmental breed is promising not only for milk production, but also for beef production. In the structure of the breed, there is the following division of livestock by production types: dairy (18-24\%), dairy and meat (40-59\%) and meat and dairy (18-26\%) [7-12].

The first breeding heifers of the Simmental breed of Austrian selection, in the amount of 400 heads, were brought to Hammer LLC in 2007. In the breeding breeding company "Hammer" from the Simmental cattle of the Austrian selection, the milk yield from one cow is more than $5000 \mathrm{~kg}$. At the same time, the economic efficiency of milk production at

\footnotetext{
*Corresponding author: pogodaev_1954@mail.ru
} 
the enterprise remains low. The main reason for this is the low purchase prices for milk set by large processing enterprises of the Republic. Therefore, Hammer began to look for ways to improve the efficiency of the use of Simmental cattle. Taking into account the natural and climatic conditions (mountain-distant cattle keeping), the farm decided to transfer part of the Simmental cattle to be kept according to the technology of beef cattle breeding.

The aim of the research was to establish quantitative and qualitative indicators of meat productivity of Simmental bull calves of various constitutional types when grown according to the technology of beef cattle breeding.

\section{Material and methods of the study}

The research and production experience was carried out in the conditions of LLC breeding producer Hammer according to the scheme presented in the table 1.

Table 1. Scheme of the experiment.

\begin{tabular}{|c|c|c|c|}
\hline Groups & Number of cows & Direction of productivity & Cow productivity \\
\hline I & 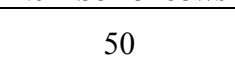 & Meat and dairy & $\begin{array}{c}3000-3500 \\
4.31 \%\end{array}$ \\
\hline II & 50 & $\begin{array}{l}\text { leaning towards meat and } \\
\text { dairy }\end{array}$ & $\begin{array}{c}3500-4000 \\
4.11 \%\end{array}$ \\
\hline III & 50 & $\begin{array}{l}\text { leaning towards milk and } \\
\text { meat }\end{array}$ & $\begin{array}{c}4000-4500 \\
3.95 \%\end{array}$ \\
\hline IV & 50 & Milk and meat & $\begin{array}{c}4500-5000 \\
3.83 \%\end{array}$ \\
\hline
\end{tabular}

For the experiment, 4 groups of 50 cows were formed. After calving, 20 calves were selected from each group, which were subsequently kept according to the technology of beef cattle breeding. During the suckling period, which lasted 205 days, the bulls were kept indoors for 4 months (from January to April) in early May, the bulls with their mothers were transferred to grazing. Weaning was carried out at the age of 205 days. During the suckling period, the amount of milk consumed was determined by weighing before and after feeding. Since the milk production of all cows exceeded the amount of milk consumed by the calves, they were supplemented.

After weaning (end of July), the bulls remained in the pasture and were kept in feeding conditions until October inclusive (92 days). At the age of 10 months, they were transferred to the premises, where they were kept from November to April of the following year inclusive (182 days). At the age of 16 months, bulls were transferred to feeding, which lasted 3 months (May - July, 92 days). Experimental animals aged 19 months were put on final fattening (August, 31 days).

Animal feeding was carried out in accordance with detailed regulations. To study meat productivity, a control slaughter of five bulls from each group at 16 and 20 months of age was carried out according to the method of VIZH, VNIIMP.

To study the qualitative indicators of beef, average samples of the pulp of a carcass weighing $400 \mathrm{~g}$, the longest muscle of the back and fat of different localization, $200 \mathrm{~g}$ each, were taken from three carcasses from each group.

\section{Results of the study}

The results of our research showed that at birth the live weight of bulls ranged from 32.1 to $33.4 \mathrm{~kg}$. 
Table 2. Dynamics of gains in live weight of experimental animals.

\begin{tabular}{|l|c|c|c|c|}
\hline \multirow{2}{*}{ Indicator } & \multicolumn{4}{|c|}{ Groups } \\
\cline { 2 - 5 } & I & II & III & IV \\
\hline Number of bulls. units & 20 & 20 & 20 & 20 \\
\hline Live weight at birth. kg & $33.4 \pm 0.05$ & $32.6 \pm 0.07$ & $32.8 \pm 0.08$ & $32.1 \pm 0.12$ \\
\hline $\begin{array}{l}\text { Live weight at weaning (205 } \\
\text { days). kg }\end{array}$ & $289.7 \pm 0.8$ & $280.7 \pm 0.5$ & $266.5 \pm 0.5$ & $253.5 \pm 0.5$ \\
\hline $\begin{array}{l}\text { Average daily gain in live } \\
\text { weight from birth - 205 days. g }\end{array}$ & $1250 \pm 3.9$ & $1210 \pm 2.6$ & $1140 \pm 2.3$ & $1080 \pm 2.8$ \\
\hline $\begin{array}{l}\text { Live weight after feeding (7-10 } \\
\text { months). kg }\end{array}$ & $369.2 \pm 0.8$ & $358.5 \pm 1.0$ & $340.5 \pm 0.9$ & $327.1 \pm 1.2$ \\
\hline $\begin{array}{l}\text { Average daily gain in live } \\
\text { weight during feeding (7-10 } \\
\text { months).g }\end{array}$ & $864 \pm 10.3$ & $846 \pm 13.8$ & $805 \pm 11$ & $800 \pm 12.4$ \\
\hline $\begin{array}{l}\text { Live weight after rearing (11- } \\
16 \text { months). kg }\end{array}$ & $537.0 \pm 1.8$ & $525.0 \pm 2.0$ & $503.9 \pm 1.9$ & $489.1 \pm 2.2$ \\
\hline $\begin{array}{l}\text { Average daily gain in live } \\
\text { weight during the growing } \\
\text { period (11-16 months). g }\end{array}$ & $922 \pm 10.2$ & $915.0 \pm 13.0$ & $898 \pm 10.3$ & $890 \pm 13.9$ \\
\hline $\begin{array}{l}\text { Live weight after feeding (17- } \\
19 \text { months). kg }\end{array}$ & $618.4 \pm 1.3$ & $605.1 \pm 1.9$ & $578.6 \pm 1.3$ & $563.6 \pm 2.0$ \\
\hline $\begin{array}{l}\text { I'll average. Live weight gain } \\
\text { during feeding (17-19 months). } \\
\text { g }\end{array}$ & $884 \pm 21.5$ & $871 \pm 34.0$ & $812 \pm 24.3$ & $809 \pm 31.9$ \\
\hline $\begin{array}{l}\text { Live weight after slaughter } \\
\text { fattening (20 months). kg }\end{array}$ & $659.3 \pm 1.9$ & $645.6 \pm 2.2$ & $618.6 \pm 1.2$ & $601.1 \pm 1.5$ \\
\hline $\begin{array}{l}\text { Average live weight gain at } \\
\text { slaughter fattening. g }\end{array}$ & $1321 \pm 80.3$ & $1306 \pm 96.1$ & $1290 \pm 59.2$ & $1210 \pm 85.2$ \\
\hline
\end{tabular}

At the same time, the live weight of the bulls of the first group significantly $(\mathrm{P}>0.999)$ exceeded the live weight of the bulls of the second - fourth groups by $0.6-1.3 \mathrm{~kg}$. (Table 2). The bulls of the second group significantly $(\mathrm{P}>0.99)$ surpassed their peers of the fourth group by $0.5 \mathrm{~kg}$, and the third group significantly $(\mathrm{P}>0.999)$ exceeded the bulls of the fourth group by $0.7 \mathrm{~kg}$.

The live weight of bulls at weaning was different, and a certain tendency revealed at birth was confirmed. The point is that cows with a lower milk yield and higher milk fat content gave birth to calves with a slightly higher live weight. At the age of 205 days, bulls of the first group $(289.7 \mathrm{~kg})$ had the highest live weight, which is significantly $(\mathrm{P}>0.999)$ higher than in the other groups by $9.0-36.2 \mathrm{~kg}$. The live weight of the bulls of the second group $(280.7 \mathrm{~kg})$ significantly $(\mathrm{P}>0.999)$ exceeded the live weight of the bulls of the third and fourth groups by 14.2 and $27.2 \mathrm{~kg}$, respectively. Finally, the live weight of bulls of the third group significantly $(\mathrm{P}>0.999)$ exceeded the live weight of bulls of the fourth group by $13.0 \mathrm{~kg}$. These data indicate that the difference in live weight, revealed at birth, during the sucking period was fixed and became more pronounced, since the difference between the second and third groups became significant.

The average daily gains during the suction period were quite high and amounted to 1080 $-1250 \mathrm{~g}$, respectively, in the fourth - first groups. The difference between the groups was significant $(\mathrm{P}>0.999)$.

The animals were kept indoors for growing. By the end of this period, the live weight of bulls of the first group (age of bulls 16 months) was $537.0 \mathrm{~kg}$ (average daily gain in live weight $-922 \mathrm{~g}$ ). This figure is $12-47.9 \mathrm{~kg}$ higher than in the second - fourth groups, respectively. As a result, the live weight of bulls of the first group was significantly (P> $0.999)$ higher than in the other groups. Also, a significant $(\mathrm{P}>0.999)$ difference was 
revealed between the live weight of bulls of the second group $(525.0 \mathrm{~kg})$ and similar indicators of the third $(503.9 \mathrm{~kg})$ and fourth groups $(489.1 \mathrm{~kg})$.

From May to July (92 days) the animals were transferred to foraging in mountain pastures. During this period, the animals reached live weight: bulls $618.4 \mathrm{~kg}$ - the first group (average daily gain in live weight $-884 \mathrm{~g}$ ), $605.1 \mathrm{~kg}$ - the second group (average daily gain $-871 \mathrm{~g}$ ), $578.6 \mathrm{~kg}$ - the third group (average daily growth $-812 \mathrm{~g}$ ) and $563.6 \mathrm{~kg}$ - the fourth group $(809 \mathrm{~g})$. The difference between all groups was significant $(\mathrm{P}>0.999)$.

In August, animals of all groups were on the final fattening (31 days). During this period, the highest average daily gains in live weight $(1321-1210 \mathrm{~g})$ were observed during the entire experiment. This made it possible by the end of the period to obtain the live weight of bulls (age 20 months) $659.3,645.6,618.6$ and $601.1 \mathrm{~kg}$, respectively, in the first - fourth groups. The difference between all groups was significant $(\mathrm{P}>0.999)$.

Thus, the higher fat content of milk characteristic of the Simmentals cattle of the meat and dairy direction (4.31\%) led to the emergence and consolidation of a significant difference in the dynamics of live weight and average daily gain in live weight of bulls for the entire period of the experiment from birth to 20 months.

An important criterion for determining the biological characteristics of young cattle according to the efficiency of feed use is the payment for feed by an increase in live weight.

Based on the consumption of feed and nutrients, as well as the increase in live weight, we found that, both in all periods of research, and for the entire period of experience, the groups of bulls obtained from mothers of meat and dairy production direction differed in the lowest feed costs per unit of production. So, in the period from birth to 7 months of age, despite the higher nutritional value of the rations, the bulls of the 1st group spent 3.61 energy feed units and $397.97 \mathrm{~g}$ of digestible protein per $1 \mathrm{~kg}$ of live weight gain, which is lower than in peers of the 4th group by 0.33 ECU and $44.67 \mathrm{~g}$ PP. Groups of experimental bulls obtained from cows that deviate in the milk-meat and meat-and-milk directions of productivity, according to these indicators, occupied an intermediate position. Similar trend in terms of the studied traits was observed in subsequent technological periods.

At the same time, it should be noted that with age, regardless of the origin of the experimental bulls, there is a tendency to an increase in feed costs for the growth of $1 \mathrm{~kg}$ of live weight. So, if during the sucking period the feed costs per $1 \mathrm{~kg}$ of live weight gain in the experimental groups of bulls are in the range of 3.61-3.94 energy feed units and 397.97$442.64 \mathrm{~g}$ of digestible protein, then in the period from birth before the end of feeding (19 months), these indicators vary within the range - 7.81-8.31 and 774.36-825.96, respectively.

As a result, over the entire period of experience, feed costs per unit of production, with a higher increase in live weight $(625.9 \mathrm{~kg})$, were the smallest in bulls born to mothers of meat and milk type - 7.93 energy feed units and $782.87 \mathrm{~g}$ of digestible protein, which is 0.52 ECU and $52.7 \mathrm{~g}$ PP lower than that of peers from dairy and beef cows with the lowest gain in live weight $-569.0 \mathrm{~kg}$.

In general, bulls of all groups were characterized by satisfactory feed costs per $1 \mathrm{~kg}$ of live weight gain. The best payment for fodder growth was distinguished by young animals born from cows of meat and dairy production direction, which must be taken into account in selection and breeding work with the studied population of Simmental cattle.

The results of the control slaughter of bulls at the age of 16 months are presented in Table 3. It was found that the removable live weight was significantly $(\mathrm{P}>0.99)$ more in animals of the first group $(537.8 \mathrm{~kg})$ compared with animals of other groups. 
Table 3. Results of control slaughter of bulls $(n=5)$.

\begin{tabular}{|c|c|c|c|c|c|}
\hline \multirow{2}{*}{ Indicator } & \multirow{2}{*}{$\begin{array}{c}\text { Age. } \\
\text { months }\end{array}$} & \multicolumn{4}{|c|}{ Group } \\
\hline & & I & II & III & IV \\
\hline \multirow{2}{*}{$\begin{array}{l}\text { Removable live } \\
\text { weight. kg }\end{array}$} & 16 & $537.8 \pm 1.8$ & $525.0 \pm 2.0$ & $503.9 \pm 1.9$ & $489.1 \pm 2.2$ \\
\hline & 20 & $659.3 \pm 1.9$ & $645.6 \pm 2.2$ & $618.6 \pm 1.2$ & $601.1 \pm 1.5$ \\
\hline \multirow{2}{*}{$\begin{array}{l}\text { Pre-slaughter } \\
\text { live weight. kg }\end{array}$} & 16 & $520.3 \pm 2.32$ & $508.1 \pm 2.11$ & $488.5 \pm 2.88$ & $473.2 \pm 2.12$ \\
\hline & 20 & $646.1 \pm 2.9$ & $628.0 \pm 5.47$ & $602.4 \pm 3.77$ & $587.5 \pm 4.88$ \\
\hline \multirow{2}{*}{$\begin{array}{l}\text { Steam carcass } \\
\text { weight. kg }\end{array}$} & 16 & $290.2 \pm 3.54$ & $279.7 \pm 2.22$ & $266.3 \pm 2.69$ & $256.1 \pm 3.41$ \\
\hline & 20 & $377.5 \pm 2.4$ & $365.1 \pm 3.92$ & $343.6 \pm 2.93$ & $332.9 \pm 3.64$ \\
\hline \multirow{2}{*}{ Carcass yield.\% } & 16 & $55.8 \pm 1.2$ & $55.1 \pm 1.9$ & $54.6 \pm 1.1$ & $54.1 \pm 1.6$ \\
\hline & 20 & $58.5 \pm 1.2$ & $58.2 \pm 1.5$ & $57.1 \pm 1.9$ & $56.7 \pm 1.2$ \\
\hline \multirow{2}{*}{$\begin{array}{l}\text { Mass of internal } \\
\text { raw fat. } \mathrm{kg}\end{array}$} & 16 & $14.0 \pm 0.87$ & $13.7 \pm 1.21$ & $13.4 \pm 1.4$ & $12.6 \pm 1.62$ \\
\hline & 20 & $17.9 \pm 1.1$ & $16.7 \pm 1.6$ & $16.1 \pm 1.21$ & $15.8 \pm 1.1$ \\
\hline \multirow{2}{*}{$\begin{array}{ll}\text { Internal } \\
\text { output. } \%\end{array} \quad$ fat } & 16 & $2.7 \pm 0.32$ & $2.7 \pm 0.69$ & $2.8 \pm 0.88$ & $2.7 \pm 0.96$ \\
\hline & 20 & $2.8 \pm 0.88$ & $2.7 \pm 0.97$ & $2.7 \pm 0.68$ & $2.7 \pm 0.61$ \\
\hline \multirow{2}{*}{$\begin{array}{l}\text { Slaughter } \\
\text { weight. kg }\end{array}$} & 16 & $304.2 \pm 2.99$ & $293.4 \pm 2.31$ & $279.7 \pm 2.14$ & $268.7 \pm 3.88$ \\
\hline & 20 & $395.4 \pm 3.44$ & $381.8 \pm 5.4$ & $359.7 \pm 3.47$ & $348.7 \pm 3.58$ \\
\hline \multirow{2}{*}{ Lethal output.\% } & 16 & $58.5 \pm 1.2$ & $57.8 \pm 2.8$ & $57.3 \pm 1.6$ & $56.8 \pm 1.0$ \\
\hline & 20 & $61.2 \pm 2.2$ & $60.8 \pm 2.1$ & $59.8 \pm 2.3$ & $59.4 \pm 1.0$ \\
\hline
\end{tabular}

At the same time, the bulls of the first group significantly $(\mathrm{P}>0.95)$ surpassed the animals of the second group in terms of pre-slaughter live weight (by $12.2 \mathrm{~kg}$ ), weight of a fresh carcass (by $10.5 \mathrm{~kg}$ ) and slaughter weight (by $10.8 \mathrm{~kg}$ ). In terms of carcass yield, internal raw fat mass, internal fat yield and lethal yield, the differences between the groups were insignificant and insignificant.

The bulls of the second group at the age of 16 months had a removable live weight of $525 \mathrm{~kg}$, which significantly ( $\mathrm{P}>0.99$ ) exceeds that of the animals of the third (by $11.1 \mathrm{~kg}$ ) and fourth (by $35.9 \mathrm{~kg}$ ). Similar situation was observed in terms of such indicators as preslaughter live weight, fresh carcass weight and slaughter weight.

At the age of 20 months, the bulls of the first group significantly $(\mathrm{P}>0.99)$ surpassed their peers in the second group in terms of removable live weight by $13.7 \mathrm{~kg}$, the third group by $40.7 \mathrm{~kg}((\mathrm{~B}>0.99)$, and the animals of the fourth group by $58.2 \mathrm{~kg}(\mathrm{P}>0.99)$. There was also a significant difference $(\mathrm{P}>0.99)$ in this indicator between the animals of the second, third and fourth groups. In terms of pre-slaughter live weight, fresh carcass weight, slaughter the weight of the bulls of the first group significantly $(B>0.99)$ exceeded their peers from other groups. In terms of the carcass yield, the mass of internal raw fat, the yield of internal fat and the slaughter yield, there was no significant difference between the groups.

A significant difference $(\mathrm{P}>0.95)$ was observed between the animals of the first and third groups when slaughtered at 16 months of age in terms of the full fleshness of the carcass (130.5 and 120.1\%, respectively). In terms of this indicator, bulls of the first and second groups were significantly $(\mathrm{P}>0.99)$ superior to their peers from the fourth group.

The bull calves of the first group at the age of 20 months significantly $(\mathrm{P}>0.95)$ surpassed their peers from the third group in terms of full body fleshness (by $14.2 \%$ ) and animals from the fourth group by $18.2 \%(\mathrm{P}>0.99)$. There was a significant difference $(\mathrm{P}>$ 0.95 ) between the animals of the second and fourth groups in terms of the full clarity of the carcass (150.0 and $137.7 \%$, respectively).

The study of the morphological composition of half-carcasses of gobies killed at 16 months of age (Table 4) showed that gobies of the first group significantly ( $>>0.95$ ) surpassed their counterparts of the third group in terms of half-carcass weight by $21.5 \mathrm{~kg}$, in terms of pulp weight - by $19,1 \mathrm{~kg}(\mathrm{P}>0.95)$. The animals of the first group significantly $(\mathrm{P}>0.99)$ surpassed their peers of the fourth group in half carcass weight (by $28.9 \mathrm{~kg}$ ), and 
in pulp weight by 25.8 ( $\mathrm{P}>0.99)$. The animals of the second group exceeded the animals of the third group in terms of half carcass weight by $10.9 \mathrm{~kg}(\mathrm{P}>0.95)$. The bulls of the second group significantly $(\mathrm{P}>0.95)$ exceeded their peers of the fourth group in terms of half carcass weight by $18.3 \mathrm{~kg}$ and meat by $14.7 \mathrm{~kg}$. There was no significant difference between the animals of the third and fourth groups according to these indicators.

Table 4. Morphological composition of bulls half carcasses $(n=5)$.

\begin{tabular}{|l|c|c|c|c|c|}
\hline \multirow{2}{*}{ Indicator } & \multirow{2}{*}{$\begin{array}{c}\text { Age. } \\
\text { months }\end{array}$} & \multicolumn{4}{|c|}{ Group } \\
\cline { 2 - 6 } & 16 & $149.0 \pm 2.16$ & $138.4 \pm 2.11$ & $127.5 \pm 2.21$ & $120.1 \pm 2.17$ \\
\hline \multirow{2}{*}{$\begin{array}{l}\text { Half carcass } \\
\text { weight. kg }\end{array}$} & 20 & $186.2 \pm 2.14$ & $184.9 \pm 2.04$ & $178.7 \pm 2.41$ & $173.6 \pm 2.01$ \\
\cline { 2 - 6 } & 16 & $119.7 \pm 2.42$ & $110.6 \pm 2.47$ & $100.6 \pm 2.37$ & $93.9 \pm 2.31$ \\
\cline { 2 - 6 } Pulp. kg & 20 & $152.5 \pm 2.41$ & $151.1 \pm 2.11$ & $145.8 \pm 2.01$ & $141.3 \pm 2.71$ \\
\hline \multirow{2}{*}{ Pulp. \% } & 16 & $80.3 \pm 2.74$ & $79.9 \pm 2.54$ & $78.9 \pm 2.74$ & $78.2 \pm 2.76$ \\
\cline { 2 - 6 } & 20 & $81.9 \pm 2.96$ & $81.7 \pm 2.36$ & $81.6 \pm 2.16$ & $81.4 \pm 2.13$ \\
\hline \multirow{2}{*}{ Bones. kg } & 16 & $26.5 \pm 1.61$ & $24.7 \pm 1.14$ & $24.1 \pm 1.04$ & $22.5 \pm 1.07$ \\
\cline { 2 - 6 } & 20 & $30.1 \pm 1.17$ & $30.1 \pm 1.07$ & $29.1 \pm 1.01$ & $28.8 \pm 1.04$ \\
\hline \multirow{2}{*}{ Bones. \% } & 16 & $17.8 \pm 1.06$ & $17.8 \pm 1.12$ & $18.9 \pm 1.02$ & $18.7 \pm 1.05$ \\
\cline { 2 - 6 } & 20 & $16.2 \pm 1.15$ & $16.3 \pm 1.05$ & $16.3 \pm 1.02$ & $16.6 \pm 1.12$ \\
\hline $\begin{array}{l}\text { Cartilage and } \\
\text { tendons. kg }\end{array}$ & 16 & $2.8 \pm 0.27$ & $3.1 \pm 0.23$ & $2.8 \pm 0.21$ & $3.7 \pm 0.24$ \\
\cline { 2 - 6 } $\begin{array}{l}\text { Cartilage and } \\
\text { tendons. \% }\end{array}$ & 16 & $3.6 \pm 0.31$ & $3.7 \pm 0.22$ & $3.8 \pm 0.23$ & $3.5 \pm 0.17$ \\
\cline { 2 - 6 } $\begin{array}{l}\text { Pulp yield per } \\
1 \text { kg of bones }\end{array}$ & 20 & $1.9 \pm 0.29$ & $2.2 \pm 0.31$ & $2.2 \pm 0.27$ & $3.1 \pm 0.28$ \\
\cline { 2 - 6 } & 20 & $4.5 \pm 0.24$ & $2.0 \pm 0.14$ & $2.1 \pm 0.11$ & $2.0 \pm 0.10$ \\
\hline
\end{tabular}

Similar picture in terms of the morphological composition of half carcasses was observed when calves were slaughtered at 20 months of age.

One of the tasks of our research was the study of the chemical composition, physicochemical and commodity-technological properties of the muscle tissue of bulls. The chemical composition of meat characterizes its nutritional properties and taste.

With age, there was an increase in dry matter content and a decrease in moisture in the average sample of meat. There was no significant difference between the groups in terms of the chemical composition of the average sample of bulls carcass meat.

It was found that the highest ratio in the longest muscle of the back protein / fat is characteristic of the bulls of the first group (18.01), the lowest ratio is observed in the bulls of the fourth group (15.37). At the age of 20 months, the moisture content of the animals of the first group was significantly $(\mathrm{P}>0.95)$ superior to the animals of the fourth group (by $0.75 \%)$.

Physicochemical and technological indicators of the longest back muscle are presented in table 5 .

Table 5. Physicochemical and technological indicators of the longest muscle of the back of the experimental bulls $(\mathrm{n}=5)$.

\begin{tabular}{|l|c|c|c|c|c|}
\hline \multirow{2}{*}{ Indicator } & \multirow{2}{*}{$\begin{array}{c}\text { Age. } \\
\text { months }\end{array}$} & \multicolumn{4}{|c|}{ Group } \\
\cline { 3 - 6 } & 16 & $5.94 \pm 0.03$ & $5.95 \pm 0.03$ & $5.92 \pm 0.03$ & $5.94 \pm 0.02$ \\
\cline { 2 - 6 } $\begin{array}{l}\text { Acidity. } \\
\text { units }\end{array}$ & 20 & $6.04 \pm 0.03$ & $6.05 \pm 0.03$ & $6.08 \pm 0.03$ & $6.04 \pm 0.03$ \\
\hline $\begin{array}{l}\text { Moisture } \\
\text { holding } \\
\text { capacity. \% }\end{array}$ & 16 & $57.88 \pm 0.93$ & $57.91 \pm 0.91$ & $57.74 \pm 0.89$ & $57.75 \pm 0.87$ \\
\hline $\begin{array}{l}\text { Color intensity. } \\
\text { units extinction }\end{array}$ & 16 & $58.78 \pm 0.77$ & $58.73 \pm 0.74$ & $58.78 \pm 0.66$ & $58.59 \pm 0.76$ \\
\hline Tenderness of & 16 & $306.12 \pm 2.81$ & $306.41 \pm 2.79$ & $306.52 \pm 2.63$ & $306.88 \pm 2.51$ \\
\cline { 2 - 6 } & 20 & $2.92 \pm 0.11$ & $2.91 \pm 0.11$ & $2.9 \pm 0.11$ & $2.92 \pm 0.11$ \\
\hline
\end{tabular}




\begin{tabular}{|l|c|c|c|c|c|}
\hline meat. $\mathrm{kg} / \mathrm{cm}^{2}$ & 20 & $2.99 \pm 0.12$ & $2.98 \pm 0.11$ & $2.99 \pm 0.12$ & $2.97 \pm 0.14$ \\
\hline $\begin{array}{l}\text { Loss of juice } \\
\text { during heat } \\
\text { treatment. } \%\end{array}$ & 16 & $40.88 \pm 0.31$ & $40.9 \pm 0.28$ & $40.91 \pm 0.29$ & $40.94 \pm 0.31$ \\
\cline { 2 - 6 } & 20 & $40.55 \pm 0.24$ & $40.52 \pm 0.22$ & $40.53 \pm 0.21$ & $40.52 \pm 0.28$ \\
\hline
\end{tabular}

Due to the increase in the age of the experimental gobies, we noted an increase in such indicators as acidity, water-holding capacity, color intensity, as well as a decrease in the tenderness of meat and loss of juice during heat treatment. There was no significant difference in these indicators between the groups aged 16 and 20 months.

When analyzing the biological value of the longissimus muscle of the experimental bulls at the age of 16 months, a significantly ( $P>0.95)$ higher content of the amino acid oxyproline was revealed in bulls of the 4th group compared to the first (by $2.05 \mathrm{mg} \%$ ). As a result, the protein-quality indicator was significantly $(B>0.95)$ higher in the bulls of the first group (5.24) compared to the bulls of the fourth group (5.11). There were no significant differences between the other groups.

This trend continued at the age of 20 months. Thus, in terms of the protein-quality indicator, the bulls of the first group significantly ( $\mathrm{P}>0.99)$ surpassed the bulls of the third group (by $0.07 \mathrm{mg} \%$ ) and the fourth group (by $0.18 \mathrm{mg} \%$ ). Also, the fourth group was superior to the bulls of the second group - by $0.17 \mathrm{mg} \%(\mathrm{P}>0.99)$.

Analysis of the data obtained indicates differences in the yield of nutrients and energy value of the pulp of the carcass.

It should be noted that in bulls of all experimental groups, with age, protein synthesis slowed down and the process of fat deposition was activated.

The value of protein and fat in bulls was $0.64-0.65$ at slaughter at 16 months of age, while at 20 months of age this ratio was 1.44-1.50.

Due to the change in the ratio of protein and fat in meat, the energy value of the pulp has also changed. At the same time, an increase in the energy value with the age of the animals was noted. So, from 16 to 20 months of age in bulls of groups I, II, III, IV, the energy value of the pulp increased, respectively, by $848,900,1149,813 \mathrm{KJ}$ or by 10.10 ; $10.70 ; 13.70 ; 10,95 \%$.

It is characteristic that the increase in the concentration of energy in all groups was due to fat, and the relative content of protein in the pulp of carcasses from the experimental groups tended to decrease.

It should be noted that the meat and dairy gobies were distinguished by the greatest amount of energy in the flesh of the carcasses. They exceeded their peers in groups II III IV by 1.56 in the amount of energy in the pulp of carcasses at the age of 16 months; 3.26; 4.07 $\mathrm{MJ}$, and at 20 months of age - by $0.14 ; 0.44 ; 1.75 \mathrm{MJ}$.

Our research has established that the animals of the experimental groups consumed different amounts of protein and feed energy per $1 \mathrm{~kg}$ of live weight gain. It is known that the absolute yield of protein and fat in the body of an animal largely determines the characteristics of their synthesis in a particular period of postembryonic development.

The calculations show that the meat and dairy gobies were distinguished by the highest amount of protein in the carcass pulp. Among peers of II III IV groups it was less at 16 months of age, respectively, by $3.44 ; 7.37 ; 9.84 \mathrm{~kg}$, and at 20 months of age, respectively, by $0.12 ; 1.19 ; 2.59 \mathrm{~kg}$.

In terms of the yield of protein, fat and energy per $1 \mathrm{~kg}$ of pre-slaughter weight, the Simmental bulls of the meat and dairy type had an advantage in all the periods studied.

The established nature of the accumulation of nutrients in the body of young animals influenced the conversion rate of protein and feed energy into food protein and the energy of the carcass pulp.

At the same time, in young animals of all experimental groups, the best ability to transform feed protein into body protein was noted at 16 months of age. By the age of 20 
months, this indicator decreased in bulls of groups I, II by $1.64 ; 0.78 \%$, and in bulls of III, IV groups this indicator practically did not change.

The highest coefficient of conversion of protein into food protein exhibited beef and dairy gobies. At the age of 16 months, they exceeded their peers in groups II, III, IV by 0.8 ; $1.78 ; 2.35$ absolute percent. By the age of 20 months, the differences in this indicator between the groups became insignificant.

When evaluating the efficiency of conversion of the metabolic energy of feed into the energy of the carcass pulp, it was found that with age, the value of this indicator in bulls of all experimental groups decreased.

The highest coefficient of conversion of metabolic feed energy into pulp energy in experimental bulls was noted at the age of 16 months. The maximum value of this indicator was characterized by beef and dairy bulls (group I). They excelled animals of groups II, III, IV at 16 months of age, respectively, by $0.45 ; 0.91 ; 0.98$ absolute $\%$. At the age of 20 months, the highest value of this indicator was characteristic of bulls of the III group $(8.76 \%)$.

\section{Conclusion}

On the basis of the studies carried out, it can be concluded that the Simmental gobies raised according to the technology of beef cattle breeding have high meat productivity.

The maximum growth rate and the highest yield of meat products were obtained from Simmental gobies of the meat and dairy type when they were raised and fed according to the technology of beef cattle breeding. Receiving from the mothers for 205 days of the sucking period more fatty milk, they gave $1250 \mathrm{~g}$ of growth per day and reached $289.7 \mathrm{~kg}$ of live weight by the time they were fed. Having retained a high growth rate in the future, at the final fattening they gave $1321 \mathrm{~g}$ of gain per day and at 20 months the live weight was $659.3 \mathrm{~kg}$. The superiority of Simmentals over analogues was natural by $3.4-13.3 \%$ by weight of the steamed carcass, by $0.4-1.8 \%$ by slaughter yield, by $1.4-11.1 \mathrm{~kg}$ by the amount of pulp in the carcass and pulp on bone by $0.1-0.3 \mathrm{~kg}$, protein in pulp by 0.12 ; $1.19 ; 2.59 \mathrm{~kg}$ and the amount of energy in the pulp by $0.14 ; 0.44 ; 1.75 \mathrm{MJ}$.

Simmental bulls of the meat and dairy type also have a high ability to transform protein and feed energy into protein and energy from the pulp of the carcass.

\section{References}

1. A.F. Shevkhuzhev, F.G. Kayumov, N.P. Gerasimov, D.R. Smakuev, Research Journal of Pharmaceutical, Bio-logical and Chemical Sciences RJPBCS 8(5), 634-640 (2017)

2. M.J. D'Occhio, P.S. Baruselli, G. Campanile, Theriogenology 125, 277-84 (2019) DOI: org/10.1016/j.theriogenology.2018.11.010

3. C.E. Andresen, C.L. Goad, L. Kriese-Anderson et al., Appl. Animal Sci. 35(1), 57-65 (2019) DOI.org/10.15232/aas.2018-01797

4. A.M. Pardo, M.A. Elzo, L.T. Gama, L.M. Melucci, Livestock Sci. 233, 103952 (2020) DOI: org/10.1016/j.livsci.2020.10395

5. P. Aparecida Cardosoda Luz, C. Andrighetto et al., Livestock Sci. 220, 83-92 (2019) DOI.org/10.1016/j.livsci.2018.11.018

6. Vohra Ashima, Syal Poonam, Madan Anshu, Probiotic yeasts in livestock sector Animal Feed Sci. and Technol. 219, 31-47 (2016) DOI: org/10.1016/j.anifeedsci.2016.05.019 
7. V. Kulintsev, M. Shakhmurzov, A. Shevkhuzhev et al., Int. J. of Engineer. and Advan. Technol. IJEAT 9(1), 4561-4 (2019) ISSN: 2249 - 8958

8. M. Tofastrud, A. Hessle, Y. Rekdal, B. Zimmermann, Norway Livestock Sci. 2 (2020)

9. V.A. Pogodaev, A.N. Arilov, A.I. Petenko et al., Research Journal of Pharmaceutical, Biological and Chemical Sciences RJPBCS 9(4), 755-759 (2018)

10. V. Kulintsev, M. Shakhmurzov, A. Shevkhuzhev et al., International Journal of Engineering and Advanced Technology (IJEAT) 9(1), 4561-4564 (2019) ISSN: 2249 8958

11. V.A. Pogodaev, V.V. Golembovsky, V.I. Komlatsky et al., IOP Conf. Series: Earth and Environmental Science 624, 012134 (2021) doi:10.1088/1755-1315/624/1/012134

12. A.A. Nigmatyanov, E.Z. Nafikova, N.A. Fedoseeva et al., IOP Conf. Series: Earth and Environmental Science 613, 012091 (2020) doi:10.1088/1755-1315/613/1/012091 